Journal of Educational Technology

\& Online Learning

Volume 3 | Issue 1 | 2020

http://dergipark.gov.tr/jetol

\title{
Discourse on student participation in the Open Distance Learning using Open Educational Resources
}

Ramashego Shila Shorty MPHAHLELE ${ }^{a}$

Matlala Violet MAKOKOTLELA ${ }^{\mathrm{b}}$

${ }^{a}$ Emphahrs@unisa.ac.za; University of South Africa, Pretoria, South Africa; ORCID: 0000-0002-9917-7089

b Emakokm@unisa.ac.za, University of South Africa, Pretoria, South Africa; ORCID: 0000-0003-0297-7408

Doi: $10.31681 /$ jetol.658130

Suggested citation: Mphahlele, R.S.S. \& Makokotlela, M.V. (2020). Discourse on student participation in the Open Distance Learning using Open Educational Resources. Journal of Educational Technology \& Online Learning, 3(1), 49-68.

\begin{tabular}{l} 
Article Info \\
\hline Received : 13.10 .2019 \\
Revised : 03.11 .2019 \\
Accepted: 01.12 .2019 \\
\hline
\end{tabular}

\begin{abstract}
The concepts Open Distance (ODL) and the Open Educational Resources (OER) are central to Higher Education around the globe. Although the OER are understood to be freely available online material that anyone can use for teaching and learning purposes, there is some evidence to suggest that majority of students in the African continent do not use the OER. On the other hand, existing research recognizes the ODL as the learning environment that breaks the barriers that limit students to access higher education such as location and distance from the university, financial pressures and other social problems. This paper reflects on the students' participation and use of OER, focusing in purposively three selected ODL institutions. Drawing from community of inquiry framework, and given the nature of the ODL environment, this paper argues that students' lack or limited participation in the use of OER seem to be dominated by what the OER can do which is promotion of access, equity and quality. This argument is presented with the full acknowledgement that access to Information and Communication Technologies (ICT) is essential to access, adapt and use the OER.
\end{abstract}

Review Article

Keywords: Cognitive presence, Community of Enquiry Framework, Open and Distance Learning, Open Educational Resources, Social presence and Teaching presence.

\section{INTRODUCTION}

One of the dominant assumptions made about Open Distance Learning (ODL) is that it has a potential to generate additional educational and economic values. This assumption is motivated by Fischer, Heise, Heinz, Moebius, and Koehler (2015) by further highlighting that the changed student needs, increased competition between organizations, different political and economic conditions, as well as new educational and technological approaches in higher education require technology to make higher education more accessible to students. This paper focuses mainly on students' participation upon gaining access through admission into the ODL institutions. 
Through a Community of Inquiry (CoI) Framework as methodological lens, the author(s) reflect on the students' participation and access of the Open Educational Resources (OER) focusing in purposively selected ODL institutions.

The journey towards the birth of OER according to Organisation for Economic Co-operation and Development (OECD, 2007) started around the year 2002 through the initiative by the Massachusetts Institute of Technology (MIT). In their report, (OECD, 2007) describes some of the early stages that led to the introduction of OERs citing sources such as (Johnstone, 2005; Moore, 2002) and emphasising that Materu (2004)'s report was viewed as the first comprehensive report that shaped the understanding of the OER. It should however be noted that the term OER as confirmed by Johnstone (2005) first came into use at a conference hosted by the United Nations Educational, Scientific and Cultural Organization (UNESCO) in 2002. It was then defined as the open provision of educational resources, enabled by information and communication technologies, for consultation, use and adaptation by a community of users for non-commercial purposes. Between the year 2002 and 2015 most often used definition of OER that was corroborated by OECD (2007) is "digitised materials offered freely and openly for educators, students and self-learners to use and reuse for teaching, learning and research. In addition, Butcher AND Moore (2015) after considering relatively few historical studies in the area of OER namely: the William and Flora Hewlett Foundation; OECD; UNESCO; Cape Town Open Education Declaration and OER commons advised that the definition of OER should include licence that is as open as possible, encourages right of access for everyone. With similar view are McGrea, Miao, and Mishra (2016) who define OER as teaching, learning and research materials in any medium, digital or otherwise, that permit no-cost access, use, reuse and repurposing by others with no or limited restrictions. In the light of the afore-mentioned definitions, this paper draws from Community of Inquiry framework in reflecting to some of the evidence that suggest that majority of students in the ODL institutions from the African continent and beyond still experience some major restrictions in accessing teaching and learning material.

\section{LITERATURE}

The literature for this paper was reviewed in relation to the students' participation in the ODL and the challenges experienced when using OERs in the ODL institutions. 


\subsection{Students' participation in ODL}

Researchers (Maritim \& Getuno, 2018) view the ODL institutions as the learning environment that were established with the aim to democratise higher education in order to break the barriers that limit students to access higher education such as location and distance from the university, financial pressures and other social problems. In addition, Pitsoe and Letseka (2018) theorise ODL as a tool with potential to empower the previously marginalized majority African populations. That being the case, Maritim and Getuno (2018, 1-15); Pitsoe and Letseka (2018, 113-125) did not only identify the roles of ODL, they also noted a need to increase the students' participation in the ODL. By drawing on the need to increase participation in the ODL, Prinsloo (2015) distinguishes participation from access however, acknowledging possible theoretical and analytical approaches to exploring participation in ODL as well as the linkage and overlaps in literature between the notions of access and participation. When defining participation in the context of South Africa, Prinsloo (2015) referred to the argument made by Chowdry, Crawford, Dearden, Goodman, and Vignoles (2013) that participation means increasing the number of students from previously disadvantaged background (lower socio economic) and minority or under-represented in the higher institutions of learning.

This paper focuses on participation of students in the teaching and learning activities when they have already enrolled in the ODL institutions. It should be noted that for students to learn effectively in the ODL institution, there should be a Ubiquitous Learning Environment (ULE) created by the course managers and designers. (Mphahlele, 2019) established that ULE can be described as a balancing technique that breaks the barriers of both time and location (physical distance) within the learning environment. For Mphahlele, the ULE as the learning environment in the ODL places varying demands on delivery and feedback methods (due to time and location) and relies on different levels of knowledge and skills thus affecting student participation. Against this background, it is worth exploring the role of OER on students' participation in the ODL based on the description of OER by McGrea et al., (2016). It should however be noted that despite the elucidated description of OER as the potential solution to students' participation in the ODL's ULE in the more cost-effective manner, Common Wealth of Learning (2015) warns about the challenges experienced in many developing countries and are discussed in the section below. 


\subsection{Challenges experienced by students when using OERs in the ODL institutions}

The authors established that most OER are digital instructional material and came to the conclusion that students may require the following in order to be able to use the OER to participate in the ODL: (1) digital literacy, (2) digital citizenship and (3) digital equity. Below the authors explain in detail the need for each of the afore-mentioned aspects for students when using the OER in the ODL.

\subsubsection{Digital literacy}

The necessity for digital literacy was identified due to the rapid growth of digital formats of information in the higher education institutions (Odede \& Jiyane, 2019). The definition of digital literacy by (Law, Woo, de la Torre, \& Wong, 2018; Odede \& Jiyane, 2019) , affirms its requirement for the students to be able to use the OER. Law et al., (2018) defines digital literacy as ability to access, manage, understand, integrate, communicate, evaluate and create information safely and appropriately through digital technologies. While Odede and Jiyane, (2019) share a similar view with Law et al., (2018), they further included digital literacy benefit for students to the definition which is an understanding of wide range of applications (e.g., word processing, presentations, web-based resources). Based on the afore-mentioned this paper argues that lack or limited digital literacy of students might negatively impact their on their use of OER which further affects participation in the ODL because the authors view digital literacy as being able to generate a deeper understating of the digital environment, evaluation of digital actions and co-creation of content with others.

A study conducted by D. Yazon, Ang-Manaig, Buama, and Tesoro (2019) to determine the relationship between digital literacy, digital competence and research productivity of educators found out that digital literacy are the set of competencies required for full participation in a knowledge society. Although the study is not linked directly with students' participation, the authors found the study relevant to highlight challenges which students with limited or lack of digital literacy might encounter. D. Yazon et al., (2019) revealed challenges such as choosing the right tools to find, use or create information. The other challenges include limited understanding on presenting themselves online, finding a person online, and using online tools and websites to find and record information online. 


\subsubsection{Digital citizenship}

The challenges associated with digital citizenship which are experienced by students when using OER in the ODL emanate mostly from the four of the nine elements of digital citizenship as described by Ribble (2015) namely access, etiquette, communication and safety and security. Before outlining the challenges in relation to the above-mentioned elements of digital citizenship, it is better to first define the digital citizenship. The definition put forward by Ribble, Bailey, and Ross (2004) clearly imply its necessity because they view digital citizenship as the norms of behaviour with regard to technology use. They further concluded the definition by assuming that one can only understand digital citizenship and the issues of technology use, abuse, and misuse through the nine general areas of behaviour that make up digital citizenship. The authors did not see a need to list or explain the nine general areas of behaviour that make up digital citizenship because for the purpose of this paper the focus is on challenges (emanating from lack or limited digital citizenship) experienced by students when using OER in the ODL. The challenges are summarised in Table 1 below

Table 1

Challenges experienced

\begin{tabular}{|c|c|c|}
\hline $\begin{array}{l}\text { Element of digital } \\
\text { citizenship }\end{array}$ & $\begin{array}{l}\text { Ideal for students to use the } \\
\text { OER }\end{array}$ & $\begin{array}{l}\text { Challenge experienced by } \\
\text { students when using OER in } \\
\text { ODL }\end{array}$ \\
\hline Digital access & $\begin{array}{l}\text { - } \begin{array}{l}\text { Equitable access for all } \\
\text { students }\end{array} \\
\text { - } \\
\text { Accommodations } \\
\text { students with } \\
\text { educational needs }\end{array}$ & $\begin{array}{l}\text { - Financial ability to have } \\
\text { technology in the home } \\
\text { because of socioeconomic } \\
\text { status, disabilities, and } \\
\text { physical location (among } \\
\text { other factors). However, } \\
\text { these opportunities are not } \\
\text { equally available to all } \\
\text { students. }\end{array}$ \\
\hline $\begin{array}{l}\text { Digital } \\
\text { communication }\end{array}$ & $\begin{array}{l}\text { Students' access and ability for } \\
\text { to use the following: } \\
\text { - Email } \\
\text { - Cell phones } \\
\text { - Personal video calls } \\
\text { (Skype) }\end{array}$ & $\begin{array}{l}\text { Some students use text } \\
\text { messaging and email shorthand } \\
\text { for formal assessments }\end{array}$ \\
\hline
\end{tabular}




\begin{tabular}{|c|c|c|}
\hline & $\begin{array}{l}\text { - } \text { Instant messaging } \\
\text { - } \text { Text messaging } \\
\text { - Blogs } \\
\text { - Wikis } \\
\text { - } \quad \text { Social networking }\end{array}$ & \\
\hline Digital etiquette & $\begin{array}{l}\text { - Using technology in ways } \\
\text { that minimize the negative } \\
\text { effects on others } \\
\text { - Using technology when it is } \\
\text { contextually appropriate }\end{array}$ & $\begin{array}{l}\text { Some of the students engage in } \\
\text { cyber bullying and the use of } \\
\text { flaming, inflammatory language }\end{array}$ \\
\hline $\begin{array}{lll}\text { Digital safety and } \\
\text { security }\end{array}$ & 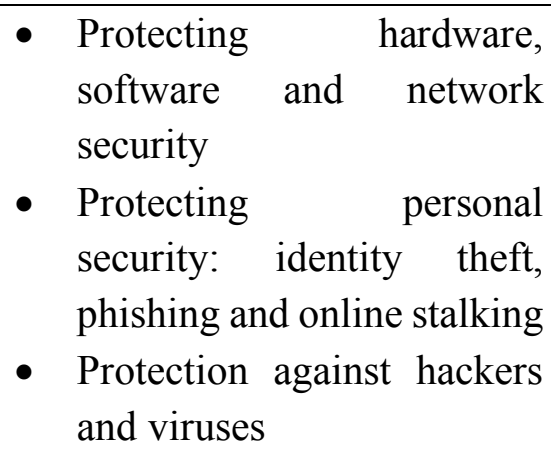 & $\begin{array}{l}\text { Financial ability to have } \\
\text { firewalls, anti-viruses and data } \\
\text { backup devices. }\end{array}$ \\
\hline
\end{tabular}

*Adapted from (Law et al., 2018; Ribble, 2015)

It should be seen from Table 1 that some of the elements such as access and safety and security pose challenges that most students might not circumvent. This paper pronounces that overcoming the challenges emanating from elements of digital citizenship has a potential to ensure mastery of responsible and appropriate technology use, including online communication etiquette and digital rights.

\subsubsection{Digital equity}

Digital equity according to Wong (2019) should be described beyond devices and on-premises infrastructure. The definition of digital equity should also emphasis the training of teachers on best practices for incorporating technology into instruction and offering students a consistent digital learning experience. Wong's argument can be grounded in some of the definitions of digital equity such as the one by Davis, Fuller, Jackson, Pittman, and Sweet (2007) which is more centred on devices. Davis et al., (2007) defined digital equity as equal access and opportunity to digital tools, resources, and services to increase digital knowledge, awareness, and skill. With the similar view as Davis et al., (2007) is Benton Institute for Broadband and Society (2016) by maintaining that digital equity ensures all individuals and communities have 
the information technology capacity needed for full participation in the society, democracy, and economy. Authors of this paper remark from their experience as the lecturers in the ODL institution that that there exist significant disparities in access to high-quality technologies and serious inequities in how different groups of students acquire technology.

Against this backdrop, this paper contends that inequality in the access to educational technology or an absence of informed guidance regarding its use can actually magnify the inequities in students' educational experiences and further limit their opportunities for employment and participation. The authors back this contention by the findings of the study conducted by (Falck, Mang, \& Woessmann, 2015; Tomer \& Kane, 2015) which revealed that there are barriers experienced by students emanating from digital equity such as outdated incompatible or unreliable computers (where they found 32 percent) and internet access not being readily available in most areas where students reside. With that in mind, this chapter theorises that lack or limited digital equity, might close up opportunities to create and share a wider array of educational resources, which might also have a negative impact on the students' access and utilisation of the OER to enhance access to educational opportunities.

\subsection{Problematising the use of OER in the ODL institutions}

Despite the fact that Common Wealth of Learning (2015) embrace OER as flexible tools that allows for the use, reuse and adaptation of materials for local contexts and learning environments, while allowing authors to have their work acknowledged. This paper argues that there is a troublesome imbalance between the provision of OER and its utilisation. OECD (2007) uncovered that the vast majority of OER are in English and based on Western culture, and this limits their relevance and risks consigning less developed countries to play the role of users. It should however be noted that, a number of projects now exist in developing countries to develop OER based on their own languages and cultures of ODL. This attempt especially in the African countries is referred to as Africanising, decolonising and transforming the education systems, which the authors view as the best way to expand student participation in the higher education. It should also be noted that for the students to utilise OER, their lecturers should first select the relevant OER and to a certain extent repurpose to the context of the course content. 


\section{METHODOLOGY}

This paper is conceptual in nature and it uses CoI Framework as methodological lens to reflect on students' participation and access of OER, focusing in particular on ODL institutions of three countries:

- India: Indira Gandhi National Open University (IGNOU)

- Mauritius: The University of Mauritius (UoM)

- South Africa: University of South Africa (UNISA)

The authors acknowledge that these universities have a broad spectrum of the differentiating qualities therefore, the author(s) employed diverse case method as one of the cross-case selection techniques. The diverse case method according to Seawright and Gerring (2008) is a selection of two or more cases intended to represent the full range of values characterizing $\mathrm{X}$, $\mathrm{Y}$, or some particular $\mathrm{X} / \mathrm{Y}$ relationship. This selection method can be used for either exploratory or confirmatory. In this study, it was employed for exploratory function focusing on student participation in the ODL using OER. The caution that 'diverse cases are likely to be representative in the minimal sense of representing the full variation of the population" (Seawright \& Gerring, 2008). With that in mind, it is worth indicating that the findings of this study may not mirror the distribution of that variation in the population.

The author(s) selected three cases (IGNOU, UoM and UNISA) with full consideration that, there is no guarantee to be representative of each category. The selection was mainly based on the following:

- They have studies conducted within the past five years about their use of OER;

- They are ODL institutions of the countries in the Commonwealth that have developed OER policies at the national level;

- Their countries are non OECD members;

- They participated in the OECD questionnaire aimed at mapping the open educational resources movement.

Firstly, the authors discuss the findings of three case studies without pretension to be exhaustive. Secondly, since the findings from the three case studies were obtained conceptually, there would be no data analysis instead authors reflected on the findings using the theoretical framework underpinning this study (Communities of Enquiry Framework). Lastly conclusions 
were made from the reflections as well as suggestions for further research, and the limitations of the current study.

The research questions guiding this study are:

- How can the OER increase student participation in the ODL institutions?

- What are the experiences of students in accessing the OERs in ODL institutions?

\section{Indira Gandhi National Open University’ case study}

The Indira Gandhi National Open University (IGNOU) case study as presented by Santosh and Santosh (2016) regards IGNOU as one of the largest ODL institution compared to the following five ODL universities in India:

- Dr. B.R. Ambedkar Open University, also known as Telangana (BRAOU), Hyderabad;

- Vardhaman Mahaveer Open University (VMOU), Kota;

- Yashwantrao Chavan Maharashtra Open University (YCMOU) Nashik;

- Netaji Subhas Open University (NSOU), Kolkotta;

- Tamil Nadu Open University (TNOU), Chennai.

The IGNOU has a capacity of 3 million cumulative student enrolment in above 40 countries, has emerged as a national resource centre for ODL, with international recognition and presence. To reach out to the unreached, the IGNOU has taken certain major initiatives towards the development of interactive multimedia content through web-based platforms. Some of the initiatives taken up at IGNOU are eGyanKosh, FlexiLearn, and Education Broadcast. FlexiLearn and Post Graduate Diploma in e-Learning (PGDEL) are presently not active because of nonexistence of a clear university policy for providing online courses and programmes of study, and for sharing and offering educational materials as OER.

Santosh and Santosh (2016) elucidate the success of IGNOU in using the OERs to the support from national policymaking bodies such as National Knowledge Commission (NKC), University Grants Commission (UGC). In the IGNOU, the lecturers are creating and using digital content for teaching and learning with the aim to embed the OER into the educational environments. The most striking aspect in this case study is the fact that IGNOU's other online programmes are not active due to non-existence of a clear university policy for providing online courses and programmes of study, and also for sharing and offering educational materials as 
OER. Despite these challenges, Santosh and Santosh (2016) concluded that the OER phenomenon has potential growth in India looking at some of the success of IGNOU.

\section{The University of Mauritius case study}

The University of Mauritius is a national university of Mauritius. It is the oldest and largest university in the country in terms of student enrolment and curriculum offered. The public university's main campus is located at Réduit, Moka. This case study was taken from the study conducted by (Wolfenden, Auckloo, Buckler, \& Cullen, 2017). They put forward the background of the University of Mauritius's involvement in the OER initiatives highlighting the hosting of a mirror site of the Massachusetts Institute of Technology (MIT) OpenCourseWare (OCW). This mirror site contributed to the European Union's Staff Improvement in Distance Education for Caribbean, African and Pacific universities (SIDECAP). There are five institutions involved in SIDECAP project, namely the Open University of the UK (project leader), the University of the Highlands and Islands Millennium Institute (UHI) in Scotland, the University of Mauritius (UoM), the University of the West Indies of Trinidad \& Tobago (UWI) and the University of the South Pacific (USP). In this project, the University of Mauritius focuses on the repurposing of OER for distance learning programmes to fit in the Mauritius context (Santally, Cooshna-Naik, Conruyt, \& Wing, 2015).

The findings from Wolfenden et al., (2017) study revealed that the University of Mauritius has made large numbers of resources freely available in digital form. However, there is as yet no formal policy on open content, and engagement with OER has typically been at the level of individual staff action. On the positive note, the use of OER helped reduce the courseware development costs and funds generated through the other paid courses made it possible to run the undergraduate diploma thereby allowing additional students to secure a place at the University on the Web and Multimedia Development Diploma.

\section{University of South Africa's case study}

In the South African context the author(s) looked at the study conducted by Cox and Trotter (2017). Their study was conducted in three different institutions of higher education but the author(s) selected the University of South Africa (UNISA) for the purpose of this paper. The reason for this selection is that UNISA has developed an institutional strategy and identified an action plan to deploy OERs. This includes infrastructure support, OER development and the use of open licenses. According to Cox and Trotter (2017) UNISA is all-inclusive, massive 
ODL institution with over 400000 students. They further posit that it is comparatively well resourced, historically multiracial and modestly privileged. The findings from Cox and Trotter's study among others indicated that many students did not have reliable access because they live in poor, rural areas with weak infrastructural support, or in urban townships far from the UNISA satellite centres. The most interesting finding in this case study is that despite the fact that developed OER strategy in 2014, their lecturers have the least control over the access of the OER and they also have relatively little control over their legal rights over the use or creation of OER.

\section{REFLECTIONS ON THE FINDINGS THROUGH THE LENS OF COMMUNITY OF INQUIRY FRAMEWORK}

As indicated in the methodology section of this paper, this section presents the authors' reflections through the lens of CoI Framework with the focus on student participation in the ODL using the OERs. Reflecting on the three case studies above, it is safe to conclude that for the students in the ODL institutions to access and use the OERs, the lecturers need to recommend or design the OER suitable for their courses. Drawing from the CoI framework, the author(s) of this study argue that the use of OER in the ODL institutions should go beyond accessing information. The institutions should focus on the elements of an educational experience that facilitate the creation of communities of students who are actively and collaboratively engaged in exploring, creating meaning, and confirming understanding (Garrison, 2017). To Garrison (2017), CoI represents the construction of knowledge through discourse and shared understanding that requires a commitment to and participation in a community of students that will support critical reflection and collaborative engagement. With this in mind, author(s) of this study maintain that student participation in the ODL can be enhanced when the use of OERs include the essential elements of $\mathrm{CoI}$ (cognitive presence, social presence, and teaching presence).

Figure 1 gives brief descriptions of the afore-mentioned elements of CoI. 


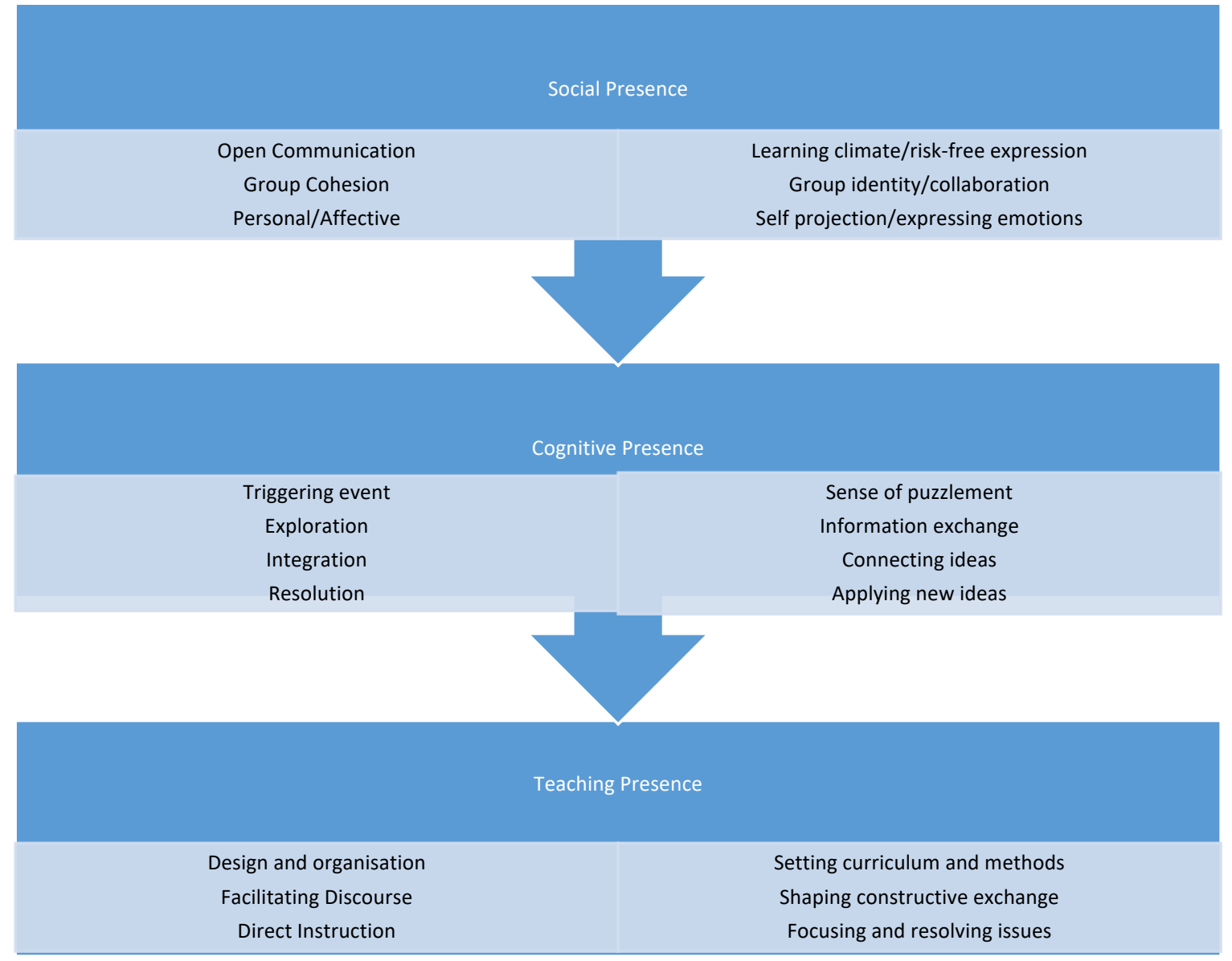

Figure1. Elements of Communities of Enquiry

Adapted from (Garrison, 2017)

It is apparent from Figure 1 that social presence can be possible when students use OERs to identify with the community (e.g., course of study), communicate purposefully with other students and lecturers, and develop inter-personal relationships by way of envisaging their individual personalities. With cognitive presence as opined by Garrison and Anderson (2003) and drawing from Figure 1 it is asserted that students can use OERs in the ODL institutions to explore and exchange information to construct meaning and confirm understanding. The data in Figure 1 demonstrates that teaching presence is hypothesized as having three responsibilities namely design, facilitation and direct instruction. Garrison (2017) proposes that these three responsibilities should be carried out in consideration of social and cognitive presence concerns. When linking the findings in the case studies with the elements of CoI framework that are illustrated by Figure 1, there is a form of interdependence, which can also be related to the two research questions guiding this study. 


\subsection{Social presence}

It is evident from the three case studies that only IGNOU and University of Mauritius are able to provide opportunities for students' social presence. The social presence is attributed to the fact that IGNOU has a capacity of 3 million cumulative student enrolment in above 40 countries using interactive multimedia content through web-based platforms. Similarly, the University of Mauritius has 5 institutions involved in its SIDECAP project and made large numbers of resources freely available in digital form. Although, Akcaoglu and Lee (2016) considers social presence (one of the elements of $\mathrm{CoI}$ ) as an imperative component of online learning but difficult to achieve. UNISA has an enrolment of over 400000 students across the globe however, those students did not have reliable access to technology because they live in poor, rural areas with weak infrastructural support, or in urban townships far from the UNISA satellite centres. Reflecting back on the challenges identified in the literature review section, authors view the challenges presented on Table 1 as having a potential to contribute towards making social presence difficult in the ODL institutions. Drawing from (Akcaoglu \& Lee, 2016)'s definitions of social presence, the authors conclude that in the ODL setting the use of OER should enable communication among students that allow appreciation of interpersonal relationships, despite the fact that they are located in different places.

\subsection{Cognitive presence}

From the case studies it is apparent that IGNOU and University of Mauritius lectures are creating digital content fort the students.

..... the success of IGNOU in using the OERs to the support from national policymaking bodies....(Santosh \& Santosh, 2016)

This paper theorises that the use of digital content for teaching and learning fosters cognitive presence in students in the sense that it allows information exchange among the students. Since IGNOU create the digital content with the aim to embed the OER into the educational environments that might address some of the challenges that emanate from digital equity. This statement is informed by the definition of digital equity by Wong (2019) who posit that digital equity exist where there is incorporation of technology into instruction and offering students a consistent digital learning experience. In the University of Mauritius the possibility of cognitive presence might result from the finding that the lecturers are repurposing the OER for distance learning programmes to fit in the Mauritius context. Even though UNISA's findings do not 
ascertain any activities directed at achieving cognitive presence, it is evident that challenges related to digital equity affect the students.

..... students did not have reliable access because they live in poor, rural areas with weak infrastructural support.....(Cox \& Trotter, 2017).

\subsection{Teaching presence}

In IGNOU, non-existence of a clear university policy for sharing and offering educational materials as OER, suggest that designing and organisation of the teaching and learning materials developed in this institutions might not facilitate the development of teaching presence. When describing teaching presence in the ODL institution, (Anderson, Rourke, Garrison, \& Archer, 2001) summarized that:

"Teaching presence begins before the course commences as the teacher, acting as instructional designer, plans and prepares the course of studies, and it continues during the course, as the instructor facilitates the discourse and provides direct instruction when required".

The University of Mauritius requires explicit policies on the way that the University is involved in the OER movement from creation to reuse, dissemination and sharing of the material. This finding highlights that lecturers using OER need to have a well-established set of guidelines that would provide a framework for the students' search and use of freely available content from the Web. Conceivably, it is noteworthy indicating that a lack of formal policy on open content, and engagement with OER, might negatively affect the institutions' teaching presence. In the sense that learning climate might not be risk-free and therefore, there would be limited exploration and application of new ideas.

It should be noted that from the three case studies, there are similarities with IGNOU and University of Mauritius context in terms of clear policies, which indicate the potential to affect all the elements of CoI unconstructively. In this study, it is perceived that it might be difficult for lecturers to facilitate discourse and difficult for students to have open communication or group cohesion/collaborations for information exchange.

\section{CONCLUSION AND SUGGESTIONS}

What the authors attempted to do in this paper is to delineate the students' participation and the use of OER in relation to the CoI framework. The authors reflected on three case studies 
involving ODL institutions from India, Mauritius and South Africa. In authors' view, through the use of OER with the focus on the CoI framework in the ODL institutions, student participation can be increased. This view answers the first research question of this paper which was formulated as follows: How can the OER increase student participation in the ODL institutions? To answer the second research question, (What are the experiences of students in accessing the OERs in ODL institutions?), it is clear that lack or limited digital equity among the students in the selected ODL institutions negatively affect the students' development of digital literacy and digital citizenship. Drawing from the reflections on case studies through the lens of CoI framework and the challenges discussed in the literature section, the authors are suggesting the following to enhance the student participation in the ODL institutions:

- Lecturers should create or repurpose the OER to the context of the ODL institution to provide students with opportunity of social interaction, collaboration, discourse and scaffolding through learning platforms. In this way there will be social, cognitive and teaching presence.

- Lecturers should profile the OLD students to be able to curb some of the challenges or barriers emanating from the digital equity. For example when designing digital content they should make sure that it will be compatible to majority if not all the students' technological tools.

- When creating or repurposing the OER, the lecturers should make sure that the students' digital literacy and citizenship are enhanced by making sure that the OER stimulate the ability for students to use all the languages that converge in the new multimedia universe and other digital platforms.

\section{LIMITATIONS AND FURTHER RESEARCH}

While the authors were able to reflect on the findings of the case studies through the lens of CoI framework, some questions remain for future research. For example the impact of the use of OER on student participation and the strategies that can be used to address the challenges emanating from digital literacy, digital citizenship and digital equity. Exploring the students' performance was beyond the scope of this study due to its nature of being conceptual. Further research, therefore, should focus on collecting empirical data from the students regarding their performance as a result of using OER. 


\section{Açık ve Uzaktan Öğrenmede Açık Kaynak Kodlu Kaynakların Kullanımının Öğrenci Katılımı Açısından Değerlendirilmesi}

\section{Özet}

Açık ve uzaktan öğrenme ve açı eğitim kaynakları kavramları yüksek öğretim için tüm dünyada önemli bir konuma gelmiştir. Açık eğitim kaynakları, öğrenme veya öğretim amaçlı olarak kullanılabilen ve ücretsiz olarak çevrimiçi ortamlardan ulaşılabilen ders materyalleri olmasına rağmen, Afrika kıtasında bulunan öğrencilerinin büyük çoğunluğunun bu kaynaklardan yararlanmadıklarına yönelik kanıtlar bulunmaktadır. Ayrıca açık ve uzaktan öğrenmenin öğrencilerin önündeki uzak mesafeler, finansal sınırlılıklar ve diğer sosyal problemler gibi yüksek öğretimin önündeki çeşitli bariyerleri ortadan kaldırdığına yönelik araștırmalar mevcuttur. Bu çalıșmada amaçlı olarak seçilen üç açık ve uzaktan öğrenme kurumunda eğitim gören öğrencilerin açık eğitim kaynaklarını kullanım durumları ve katılım durumları yansıtılmaktadır. Sonuç olarak öğrencilerin açık eğitim içeklerine sınırlı erişimleri veya hiç erişmemeleri durumu, bu içeriklerin kalite, eşitlik ve erişim konularında öğrencilere yapabilecekleri katkı bağlamında tartışılmıştır. Bu tartışma, öğrencilerin bilgi ve iletişim teknolojilerine erişimlerinin açık eğitim kaynaklarının adaptasyonu ve kullanımı için gerekli olduğu bağlamında sunulmuştur.

Anahtar Kelimeler: Bilişsel buradalık, sorgulayıcı öğrenme toplulukları, açık ve uzaktan öğrenme, açık eğitim kaynakları, sosyal buradalık ve öğretim buradalı̆̆ı.

\section{About the Author(s)}

\section{Ramashego Shila Shorty Mphahlele}

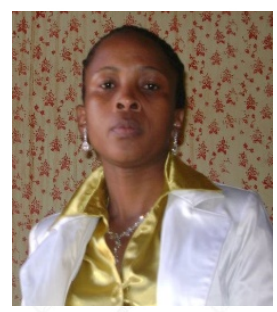

Mphahlele Ramashego Shila Shorty obtained Doctor of Education's degree from University of South Africa, Department of Psychology of Education in 2018. She has been employed as a lecturer at University of South Africa, Department of Early Childhood Education. Her interest areas are Information and Communication Technologies, Open and Distance Learning, Open Educational Resources, Mathematics teaching and student support.

Mailing Address: 135 Phudufufu Street, Atteridgeville, 0008: University of South Africa, Early Childhood Education, Pretoria, South Africa, 0008,

E-mail: Emphahrs@unisa.ac.za

\section{Matlala Violet Makokotlela}

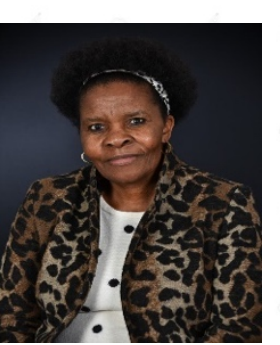

Matlala Violet Makokotlela is a lecturer at the University of South Africa (UNISA) in the Department of Science and Technology Education. She holds a Doctoral degree obtained from Unisa. Makokotlela's research interest is in curriculum, sustainability education, climate change, Open and Distance Learning and Open Education Resources.)

Mailing Address: 89 Windmill, Mooiklof Ridge, 0048, University of South Africa, Department of Science and Technology Education, Pretoria, South Africa, MatlaVi12,

E-mail: Emakokm@unisa.ac.za

\section{REFERENCES}

Akcaoglu, M., \& Lee, E. (2016). Increasing social presence in online learning through small group discussions. International Review of Research in Open and Distributed Learning, 17(3), 1-17. doi:10.19173/irrodl.v17i3.2293

Anderson, T., Rourke, L., Garrison, R., \& Archer, W. (2001). Assessing teaching presence in a computer conferencing context. Journal of Asynchronous Learning Networks, 5(2), 117. doi:10.24059/olj.v5i2.1875 
Benton Institute for Broadband and Society. (2016). What do we mean when we say 'Digital equity' and 'Digital inclusion'?. Evanston, Illinois: Benton Institute for Broadband and Society.

Butcher, N., \& Moore, A. (2015). Understanding open educational resources. Burnaby, British Columbia, Canada: Commonwealth of learning.

Chowdry, H., Crawford, C., Dearden, L., Goodman, A., \& Vignoles, A. (2013). Widening participation in higher education: Analysis using linked administrative data. Journal of the Royal Statistical Society: Series A (Statistics in Society), 176(2), 431-457. doi:10.1111/j.1467-985X.2012.01043.x

Common Wealth of Learning. (2015). Guidelines for open educational resources (OER) in higher education. Paris: United Nations Educational, Scientific and Cultural Organisation.

Cox, G., \& Trotter, H. (2017). Factors shaping lecturers' adoption of oer at three south african universities. In C. Hodgkinson-Williams, \& P. B. Arinto (Eds.), Adoption and impact of OER in the global south (pp. 287-348). Cape Town: African Minds. doi:10.5281/zenodo.1094852 Retrieved from https://search.datacite.org/works/10.5281/zenodo.1094852

D. Yazon, A., Ang-Manaig, K., Buama, C. A. C., \& Tesoro, J. F. B. (2019). Digital literacy, digital competence and research productivity of educators. Universal Journal of Educational Research, 7(8), 1734-1743. doi:10.13189/ujer.2019.070812

Davis, T. J., Fuller, M. M., Jackson, S., Pittman, S., \& Sweet, J. (2007). A national consideration of digital equity. (). Washington, D.C: International Society for Technology in Education. Retrieved from http://www.iste.org/digitalequity

Falck, O., Mang, C., \& Woessmann, L. (2015). Virtually no effect? different uses of classroom computers and their effect on student achievement. Bonn, Germany: Institute for the Study of Labor (IZA). 
Fischer, H., Heise, L., Heinz, M., Moebius, K., \& Koehler, T. (2015). How to identify e-learning trends in academic teaching. Interactive Technology and Smart Education, 12(1), 3143. doi:10.1108/ITSE-09-2014-0031

Garrison, R. D. (2017). E-learning in the 21st century: A community of inquiry framework for research and practice (3rd ed.). London: Routledge. Retrieved from https://search.credoreference.com/content/entry/igidl/communities_of_inquiry in_onli $\underline{\text { ne learning/0 }}$

Garrison, R. D., \& Anderson, T. (2003). E-learning in the 21st century: A framework for research and practice. London: Routledge/Falmer.

Johnstone, S. (2005, ). "Open educational resources and open content, background note",

Law, N., Woo, D., de la Torre, J., \& Wong, G. (2018). A global framework of reference digital on literacy skills for indicator 4.4.2. Motreal, Quebec: UNESCO.

Maritim, E. K., \& Getuno, D. M. (2018). Scalability of learners' success rates in e-learning: A survey study of the learners' perspectives. European Journal of Open, Distance and ELearning, 21(1), 1-15. doi:10.2478/eurodl-2018-0001

Materu, P. N. (2004). Open source courseware: A baseline study. Washington, DC: The World Bank.

McGrea, R., Miao, F., \& Mishra, S. (2016). Open educational resources: Policy, costs and transformation. In F. Miao, Mishra Sanjaya \& R. McGreal (Eds.), Open educational resources:Policy, costs and transformation (pp. 1-12). Paris: UNESCO.

Moore, A. H. (2002). Lens on the future: Open-source learning. EDUCAUSE Review, 37(5), 42. Retrieved from https://search.proquest.com/docview/218195918

Mphahlele, R. S. (2019). Online learning support in a ubiquitous learning environment. In G. Durak, \& S. Çankaya (Eds.), Managing and designing online courses in ubiquitous learning environments (pp. 1-18). Hershey, Pennsylvania: IGI Global. doi:10.4018/978- 


\section{1-5225-9779-7.ch001 $\quad$ Retrieved from $\underline{\text { http://services.igi- }}$ global.com/resolvedoi/resolve.aspx?doi=10.4018/978-1-5225-9779-7.ch001}

Odede, I. R., \& Jiyane, G. (2019). Exploring dimensional constructs of digital literacy skills for higher education. Library Philosophy and Practice (E-Journal),

OECD. (2007). Giving knowledge for free: The emergence of open educational resources. (). Paris: OECD. Retrieved from http://apo.org.au/?q=node/16547

Pitsoe, V., \& Letseka, M. (2018). Access to and widening participation in south african higher education. In J. Hoffman, P. Blessinger \& M. Makhanya (Eds.), Contexts for diversity and gender identities in higher education: International perspectives on equity and inclusion (pp. 113-125). Bingley, United Kingdom: Emerald Publishing Limited. doi:10.1108/S2055-364120180000012009 Retrieved from http:/www.emeraldinsight.com/10.1108/S2055-364120180000012009

Prinsloo, P. (2015). Participation in open distance learning. In M. Letseka (Ed.), Open distance learning (ODL) in south africa (pp. 21-37). New York: Nova Publishers.

Ribble, M. S. (2015). Digital citizenship in schools: Nine elements all students should know (3rd ed.). Virginia: International Society for Technology Education.

Ribble, M. S., Bailey, G. D., \& Ross, T. W. (2004). Digital citizenship: Addressing appropriate technology behavior. Learning \& Leading with Technology, 32(1), 6.

Santally, M., Cooshna-Naik, D., Conruyt, N., \& Wing, C. (2015). A social partnership model to promote educators' development in mauritius through formal and informal capacitybuilding initiatives. Journal of Learning for Development, 2(1) Retrieved from http://hal.univ-reunion.fr/hal-01375627

Santosh, S., \& Santosh, P. (2016). Use of open educational resources in distance educationopportunities and challenges in indian scenario. Staff and Educational Development International, 20(1), 39-54. doi:10.1080/01587919.2012.692068 
Seawright, J., \& Gerring, J. (2008). Case selection techniques in case study research: A menu of qualitative and quantitative options. Political Research Quarterly, 61(2), 294-308. doi:10.1177/1065912907313077

Tomer, A., \& Kane, J. (2015). Broadband adoption rates and gaps in U.S. metropolitan areas. ().The Brookings Institution. Retrieved from Social Science Premium Collection Retrieved from https://search.proquest.com/docview/1820832046

Wolfenden, F., Auckloo, P., Buckler, A., \& Cullen, J. (2017). Teacher educators and oer in east africa: Interrogating pedagogic change. In C. Hodgkinson-Williams, \& P. B. Arinto (Eds.), Adoption and impact of OER in the global south (pp. 251-286). Cape Town: African Minds. doi:10.5281/zenodo.1094850 Retrieved from https://search.datacite.org/works/10.5281/zenodo.1094850

Wong, W. (2019). Digital equity: How far have we come? EdTech. 